\title{
Economic Shocks on Subjective Well-Being: Re-assessing the Determinants of Life-Satisfaction After the 2008 Financial Crisis
}

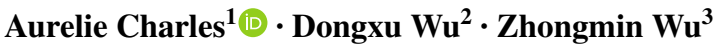

Published online: 17 April 2018

(C) The Author(s) 2018

\begin{abstract}
The paper investigates the extent to which life-satisfaction is biased by peercomparison by looking at the relative value attached to the different domains of life-satisfaction, as suggested by Easterlin (Economics and happiness: framing the analysis, Oxford University Press, New York, 2005), by social group. We postulate that group membership influences the ranking of the satisfaction domains affecting subjective well-being which allows individuals to go back to their individual threshold over time. Using ordered probit models with random effects, the evidence for professional (self-employed vs. employee) and social (male vs. female) groups using the British Household Panel Survey and Understanding Society-UK Household Longitudinal Study from 1996 to 2014 shows that the ranking of the satisfaction domains is group-based suggesting a "keeping up with the Joneses" effect linked to the housing bubble.
\end{abstract}

Keywords Panel data $\cdot$ Subjective well-being $\cdot$ Financial crisis $\cdot$ Group behaviour

JEL Classification $\quad$ C3 $\cdot$ D6 $\cdot$ D7

\section{Introduction}

The literature on subjective well-being (SWB) has made significant progress over the past 20 years, yet little is known the influence of group membership on SWB, and in particular

Aurelie Charles

A.Charles@bath.ac.uk

Dongxu Wu

wudongxu@chinatmcc.com

1 Department of Social and Policy Sciences, Centre for Development Studies, University of Bath, Bath, UK

2 Transcontinental Research Institute, Beijing, China

3 Nottingham Business School, Nottingham Trent University, Nottingham, UK 
on the relative value of the different domains of life-satisfaction. SWB tends to move around an individual setpoint and most unexpected life circumstances will move people temporarily away from that setpoint (Kahneman and Tversky 2000; Easterlin 2005; Frey 2008). Adaptive behaviour then tends to bring individuals back to their setpoint of happiness over time (Binder and Coad 2010, 2011). An economic shock such as the 2008 financial crisis is therefore expected to have moved people away from that setpoint, at least in the short-run. One of the reasons put forward which has led to the financial crisis is that, "keeping up with the Joneses" or imitation behaviour to enhance personal social status has helped to build up of the housing bubble in the US (Arestis et al. 2015). This paper investigates the extent to which subjective well-being by group rather than individual has been affected by the housing bubble in the built-up towards the financial crisis and in the aftermath of the crisis. Our research objective is to understand the extent to which remembered utility (Kahneman and Tversky 2000) is biased by peer-comparison by looking at, as suggested by Easterlin (2005), the relative value attached to the different domains of life-satisfaction for professional (self-employed vs. employee) and social (male vs. female) groups, and the extent to which they are coherent within and between groups before and after 2008 .

The methodology used to estimate the determinants of subjective well-being (SWB) matters to understand its dynamics (Ferrer-i-Carbonell and Frijters 2004; Binder and Coad 2010). While OLS models in psychology and probit/logit models in economics are used on individual data, we build from recent developments in the literature around group membership (Akerlof and Kranton 2010; Goette et al. 2006; Charness and Sutter 2012; Brown and Yang 2015) to assess SWB by socio-economic group. As such, group membership is expected to affect the ranking of life domains while the financial crisis is expected to change this ranking over time. The empirical hypotheses tested here are whether the ranking of the determinants of life-satisfaction are group-based, and whether they are similar prior and after the crisis. Using an ordered probit model, we test for the determinants of SWB in the UK for professional (self-employed vs. employee) and social (male vs. female) groups from 1996 to 2014. The data used is from the British Household Panel Survey (BHPS) for the periods 1996-2000, and 2002-2008, and its follow-up dataset Understanding Society-UK Household Longitudinal Study (UKHLS) for the period 2009-2014. The estimations are carried out separately for each period and separately for employees and self-employed individuals, whether they are men and women.

The paper is organized as follows: Sect. 2 looks at the SWB literature on the SWB threshold and on the impact of external shocks on this threshold. Section 3 explains the model based on group membership, methodology and data used in the context of the UK. The empirical results are presented in Sect. 4 before concluding in Sect. 5 .

\section{Subjective Wellbeing and External Shocks}

Several studies have pointed out the dynamic character of individual SWB whereby an individual facing a choice will seek the happiest outcome. Kahneman and Tversky (2000) and Layard (2005) for example have brought utility maximization into a dynamic process between time $t-1$ and time $t$ whereby an individual perception of SWB results from a decision prior to taking that decision. Similarly, in Rayo and Becker's model of happiness (2005), the happiness function depends extensively on whether current success exceeds a given threshold of reference. In that view, unexpected changes will affect happiness by moving away from this threshold. While it is not clear how the threshold is set in absolute 
terms, the impact of surprise tends to decrease marginally over time via adaptation to life circumstances and peer comparison. In the context of the 2008 financial crisis, our interest is to understand how the very nature of such event linked to a housing bubble and related group behaviour impacted on this SWB threshold.

The presence of a threshold in relation to SWB came to light with the Easterlin Paradox (Easterlin 1974, 1995, 2005). In Easterlin's (1995: 35) own words: "within a country at a given time those with higher incomes are, on average, happier. However, raising the incomes of all does not increase the happiness of all”, and beyond a certain income level, any further increase in income makes little or no difference to overall SWB levels (Easterlin 1995; Pouwels et al. 2008). It is however not clear how individuals adjust back to that threshold when economic shocks occur. The role of relative income has been the most common way to explain the Easterlin Paradox (McBride 2001). Individuals compare personal income to their peers, so that the impact of the increase in their own absolute income on SWB can be cancelled out by their peers' relative income increases. Hence, such explanation signals a group effect on how individuals assess and re-assess their life circumstances in comparison with "peers". In other words, group membership means that individuals share comparable circumstances and experiences with group members that can thus be qualified as peers.

Peer comparison leads individuals to compare themselves with other individuals with whom they perceive to belong to the same group(s). Such group effect is unconscious and leads to cognitive biases in individual decision-making (Akerlof and Kranton 2010), as shown for example by Bertrand et al. (2005) with the instance of implicit discrimination. The literature on group membership also shows that group behaviour tends to be more self-centred and predictable than individual behaviour (Bornstein et al. 2004; Charness and Sutter 2012; Brown and Yang 2015). In the experimental laboratory setting, Bornstein et al. (2004) provide evidence from experiments with strategic games that group members are more rational in terms of maximising the payoff for each group member, and that they are less pro-social toward other groups. Group players assume that players in other groups behave similarly which triggers a self-reinforcing norm to maximise the group's aspirations for higher payoffs. Outside the laboratory setting, Brown and Yang (2015) show that the relative social value between men and women leads women to be underestimated by the betting system in jump racing, where, as jockeys they can compete equally. In the social setting, group membership strongly affects the individual's perception of life circumstances through peer comparison. As pointed out by Dolan et al. (2008: 105), "perceptions of our circumstances can be very important predictors of life satisfaction". In effect, in their comprehensive literature review of the factors associated with SWB, the word "perception" itself appears six times for six different factors. Hence, since group membership influences the individual's perception of life circumstances, we wonder the extent to which group membership influences SWB.

We postulate that group membership influences the ranking of the life domains affecting SWB which then allows individuals to go back to their individual threshold. Personal circumstances such as health-related or the loss of relatives will however move individuals away from their individual threshold without a resilient effect (Easterlin 2005). To assess this proposition, we need to assess SWB by group and its evolution over time. Most studies in economics and psychology relate to SWB from the point of view of the individual (Diener and Suh 2000; Kahneman and Tversky 2000). In most cases, SWB refers to the self-evaluation of people's lives but the way group membership influence self-evaluation is not clear. Kahneman and Krueger's work (2006) helps our understating in that respect since they have been investigating the difference between the affect an individual experiences at 
time $t-1$, what is called experienced utility, and the way individuals remember this affect at time $t$, what is called remembered utility. The time difference leads to a systematic bias of perception between the two, and that it is linked to the judgement individuals make at time $t$ over an experience occurring at time $t-1$. Personal judgement is thus influenced by peer-comparison, involving the different social groups to which individuals belong and to self-define as 'peers'. Kahneman and Krueger (2006) further show that life circumstances have a greater impact on experienced rather than remembered utility which means that external shocks on an individual's subjective well-being will have an impact on experienced utility, which will then be biased by peer comparison with remembered utility. Urry et al. (2004) have also shown that the correlation between remembered utility and brain readings is minimal (around 0.30), which tend to suggests that reporting at time $t$ a level of utility experienced at time $t-1$ gives an inaccurate picture of experienced utility. Such findings support the view that investigating self-reported satisfaction levels in different domains of life accurately measure remembered utility biased by peer comparison, and not experienced utility. This is important when considering the impact of a peer or group effect on individual behaviour because individual choice is based on remembered utility rather than experienced utility.

At the level of remembered utility, group membership influences individual SWB by affecting the hierarchy of life domains in the SWB function. For example, the dominant norm for self-employed individuals may be to value their job on a higher scale than employed individuals. Here, the argument is not concerned with the heterogeneity versus homogeneity of groups but rather that, since remembered utility is affected by peer comparison, individual perception of life circumstances is influenced by the hierarchy of the life domains of the groups to which they belong. Then, since each individual belongs to multiple groups, the ranking of the life domains should be revealed at the group rather than individual level, and it should also differ according the intersection of groups investigated, for example, a female self-employed plumber versus a male employed plumber. In effect, as pointed out by Crenshaw (1989), the intersectionality of group memberships can lead to different normative outcomes compared with considering groups separately.

Together with peer comparison, adaptation to life circumstances through adaptive preferences or hedonic adaptation has been highlighted as another important factor that will return SWB to its individual threshold (Clark et al. 2005, 2008; Binder and Coad 2010, 2011). From the happiness perspective, the "endowment effect" (Huck et al. 2005) or "treadmill effect" Kahneman and Tversky (2000) shows that people have a tendency to get used to life circumstances in the sense that they adapt their perceptions and judgments to get back to their individual threshold. Further evidence of adaptive preferences has been gathered by Burchardt (2005) in the context of constant and increasing incomes, linking the argument to the risk-aversion of individuals. The argument put forward by Rabin (2001) however is that risk aversion is intrinsically linked to utility derived from wealth rather than income. In effect, March (1988) shows that risk aversion and risk-taking behaviour depend on wealth outcomes compared to aspiration levels of wealth. Since housing is a major component of wealth (Campbell and Cocco 2007), SWB housing factors are expected to affect negatively the SWB setpoint when a house bubble bursts as life circumstances changes the aspiration levels on wealth, at least in the short-run. Other life circumstances such as marriage, serious injuries, death of relatives or job loss also tend to "deflect a person above or below this setpoint, but in time hedonic adaptation will return an individual to the initial position" (Easterlin 2005: 29). SWB is therefore an evolutionary process (Rayo and Becker 2005) with peer comparison and adaptation to life circumstances as two major vehicles allowing external shocks to impact on the individual SWB threshold. 
Drawing on both psychological and economic empirical studies, Easterlin (2005) demonstrated that SWB depends on a variety of pecuniary and non-pecuniary domains and that their relative value for individuals is essential in influencing this threshold. The insight of Easterlin's work that this research is starting from is that attainment in each domain is not the key to happiness, but rather the relative value attached to all domains. In particular, we postulate that this relative value depends on adaptive and interdependent preferences vis-à-vis other group members and between groups. As such, external economic shocks affect the relative value of domains within and across groups. While economic shocks are likely to have an impact on net affect, or experienced utility at time $t-1$, by affecting life circumstances, it does not necessarily show in life satisfaction figures which are biased by peer comparison. The evidence collected by Dolan et al. (2008: 106) on attitude towards unemployment and inflation by political groups in effect "lend support to the idea that the impact of external circumstances is dependent upon perceptions and attitudes". Hence, economic shocks that have a group effect component, such as herd behaviour leading to a housing bubble, is likely to influence the bias brought about by peer comparison that affect life satisfaction or remembered utility at time $t$.

\section{Subjective Wellbeing and Group Membership: Model and Methodology}

This section introduces the SWB model aggregated at the group level to show the impact that the intersectionality of group membership has on the ranking of the domains of life-satisfaction. For this purpose, the model follows the existing literature (Van Praag et al. 2003; Ferrer-i-Carbonell and Frijters 2004) making life satisfaction dependent on observable domain satisfactions, and unobserved variables which include the bias brought about by group membership and that this analysis seeks to reveal. The model is then estimated using the BHPS and UKHLS data from 1996 to 2014 on two professional groups (self-employed and employee) with two layers of group membership (male and female) leading to four different groups, namely male/self-employed, male/employee, female/self-employed, and female/employee categories.

\subsection{Ordered Logit Model with Random Effect}

At the group level, General Satisfaction (GS) depends on the domain satisfactions and a latent component $Z$ for unobserved variables. Following Van Praag et al. (2003), the model assumes that there is a set $\mathrm{X}$ of objectively measurable explanatory variables $X_{1}, \ldots, X_{m}$ that explain the various domain satisfactions denoted $D S_{1}, \ldots, D S_{n}$. GS is described as:

$$
G S_{j t}=G S\left(D S_{1}, \ldots, D S_{n} ; Z\right) \quad j=1,2, \ldots, J
$$

and the domain satisfactions by a set of functions,

$$
D S_{n}=D S_{n}\left(x_{n}, Z\right) \quad n=1,2, \ldots, N
$$

where $x_{n}$ stands for the sub-selection of $x$ observable variables for the domain $n$.

The ranking of $D S_{n}$ in $G S_{j t}$ varies across groups and in the event of an external shock on $G S_{j t}$ the ranking of $D S_{n}$ will change to adjust $G S_{j t}$ back to its individual threshold through peer-comparison within and across groups. At the individual level $i=1,2, \ldots, I$, we use the assumption that GS is ordinally comparable between individuals with the main model of latent variable form being (Ferrer-i-Carbonell and Frijters 2004): 


$$
\begin{aligned}
& G S_{i t}^{*}=x_{i t} \beta+\varepsilon_{i t} \\
& G S_{i t}=k \Leftrightarrow \lambda_{k} \leq G S_{i t}^{*}<\lambda_{k+1}
\end{aligned}
$$

where $\varepsilon_{i t} \perp x_{i t}$; GS $S_{i t}^{*}$ is the latent variable and $G S_{i t}$ is observed general satisfaction. We use statistical assumption from Ferrer-i-Carbonell and Frijters (2004) that unobserved factors in $\varepsilon_{i t}$ are related to observed factors: $o v\left(\varepsilon_{i t}, x_{i t}\right)=z_{i t}$, where $z_{i t}=f\left(j \varepsilon_{i t-1}, x_{i t}\right)$ with $j$ represents the unknown bias brought by group memberships in $\varepsilon_{i t-1}$ from experienced utility at time $t-1$ to remembered utility at time $t$. Being an individual experience per se, experienced utility is difficult to assess empirically except with instant MRI scans of the brain (Kahneman and Krueger 2006). Instead, here, group membership is captured by estimating model (3) at different points in time. Estimating $G S_{i t}$ at time $t-1, t$, and $t+1$ is thus expected to reflect remembered utility at three different points in time to show the evolution of group biases on the ranking of domains satisfaction. Model (3) can be estimated with random effects, which is in line with the methodology suggested by Ferrer-iCarbonell and Frijters (2004).

\subsection{Data Analysis}

The data used is from the British Household Panel Survey (BHPS) for 1996-2000, and 2002-2008, and from its follow-up data set Understanding Society-UK Household Longitudinal Study (UKHLS) for 2009-2014. The BHPS started in 1991 and follows the same representative sample of individuals and their households where each adult member is interviewed. BHPS was then integrated into the UKHLS in 2009. Both surveys are designed to capture life in the UK and how it is changing over time and contain information about individuals' social and economic circumstances, attitudes, and health outcome. A key attribute of the UKHLS is its large sample size of 40,000 households (Knies 2015). The SWB variable is measured based on the question "how dissatisfied or satisfied are you with your life overall?" The answer runs from 1 (not satisfied at all) to 7 (completely satisfied). For the BHPS, the sample period included here is 1996-2000, and 2002-2008, waves $6-10$, and waves $12-18$, as this question starts from wave 6 (1996) only and was not asked in wave 11 (2001). The pre-crisis era will therefore be from 1996 to 2008 in line with the trend that in that period, the price of an average home increased by $215 \%$ (The Economist 2008). We complete the sample by using UKHLS, waves 1-5, for the post-crisis period 2009-2014. We use income, home ownership, house rented, problem paying for housing, hours worked, spouse/partner's pay, age, marriage, marital status, housing, health and education as explanatory variables.

Using cross-section survey data, research has found a positive impact of income on SWB up to a certain threshold, for both developed and developing countries (Blanchflower and Oswald 2004; Lelkes 2006). The dynamic relation between income and SWB, i.e., how changes in income affect changes in SWB, has also been estimated using panel data to control for unobserved individual effects to find that there is a causal effect of income on SWB (Ravallion and Lokshin 2002; Frijters et al. 2006). To account for nonlinearity, we include income squared, spouse/partner's pay squared, and age squared since using logincome in SWB equations may hide important departures from log-linearity (Clark et al. 2008). Other research use household income as income variable (Boes and Winkelmann 2004; Stutzer and Frey 2006; Booth and van Ours 2009; Ferrer-i-Carbonell and Frijters 
2004; Giusta et al. 2011). We however include both own income and spouse/partner's pay ${ }^{1}$ as they are likely to affect the peer comparison effect we seek to capture. Health is another important determinant of SWB as pointed out above that makes individuals depart from their individual (Easterlin 2005). We therefore use four health dummy variables: excellent health, good health, poor health and very poor health, with fair health as reference.

\section{Results and Discussion}

Consistently with the research objective of understanding how a particular intersectionality of group memberships affects the ranking of domains satisfaction over time, the results presented here provide a classification of SWB domain coefficients by size for all three periods tested across the four groups. In particular, the results show how time, i.e. estimating the same equation in three different periods, change the ranking of domains consistently for each group. In particular, a feature of the 2008 Great Recession around the household debt crisis is reflected in the results whereby housing domains have steadily increased in ranking across groups up to 2008 before collapsing to the lowest ranks of SWB domains in the post-2008 era.

The results for periods 1996-2001, 2002-2008, and 2009-2014 are presented in Tables 1, 2, and 3, respectively. Looking at Tables 1, 2 and 3, the results are consistent with the existing literature whereby own income, partner's pay, marital status (married, divorced or separated), and good health tend to have a positive effect on SWB, while poor health, age, and working hours-apart for self-employed men from 1996 to 2008, ${ }^{2}$ tend to have a negative effect. The age effect on SWB is similar to the results in the existing literature whereby SWB initially falls with age and bottoms out around 40 for British people before increasing again (Blanchflower and Oswald 2004; Chang 2011; Oswald and Powdthavee 2008). In terms of income, our "income squared" variable has a negative influence on SWB, which is significant at the $1 \%$ level for male and female employee. Raising the income increases the SWB, with the peak being reached at a very high level of income. However, this effect becomes smaller for higher incomes before eventually turning negative. Our results are consistent with Mentzakis and Moro (2009) who use different specification to find that higher absolute income increases SWB up to a certain threshold.

Home ownership has a positive effect on SWB, which is consistent with the findings of D'Ambrosio and Frick (2012). In Tables 1 and 2, home rental has a positive impact on SWB from 1996 to 2008, but the coefficients become negative in Table 3 from 2009 to 2014 which is likely to be linked to the 2008 financial crisis. Across the period 1996-2014, problems paying for housing are detrimental for SWB and are comparable to having poor health; though no where near as bad as very poor health. For the four groups, the health variables are significant at the $1 \%$ level for all levels of health with poorer health ratings linked to high negative coefficients. In Table 1, very poor health is the highest coefficient influencing SWB for male employees, female self-employed and employees, while the highest coefficient for self-employed men in that 1996-2000 period is linked to social

\footnotetext{
1 Data is not available for the variable "spouse/partner's pay" in the UKHLS, so it cannot be included in the estimation for the period 2009-2014.

${ }^{2}$ Gash et al. (2012) find that decreases in working hours for women bring positive and significant improvement in SWB.
} 
A. Charles et al.

Table 1 Determinants of well-being using Ordered Probit Model (1996-2000)

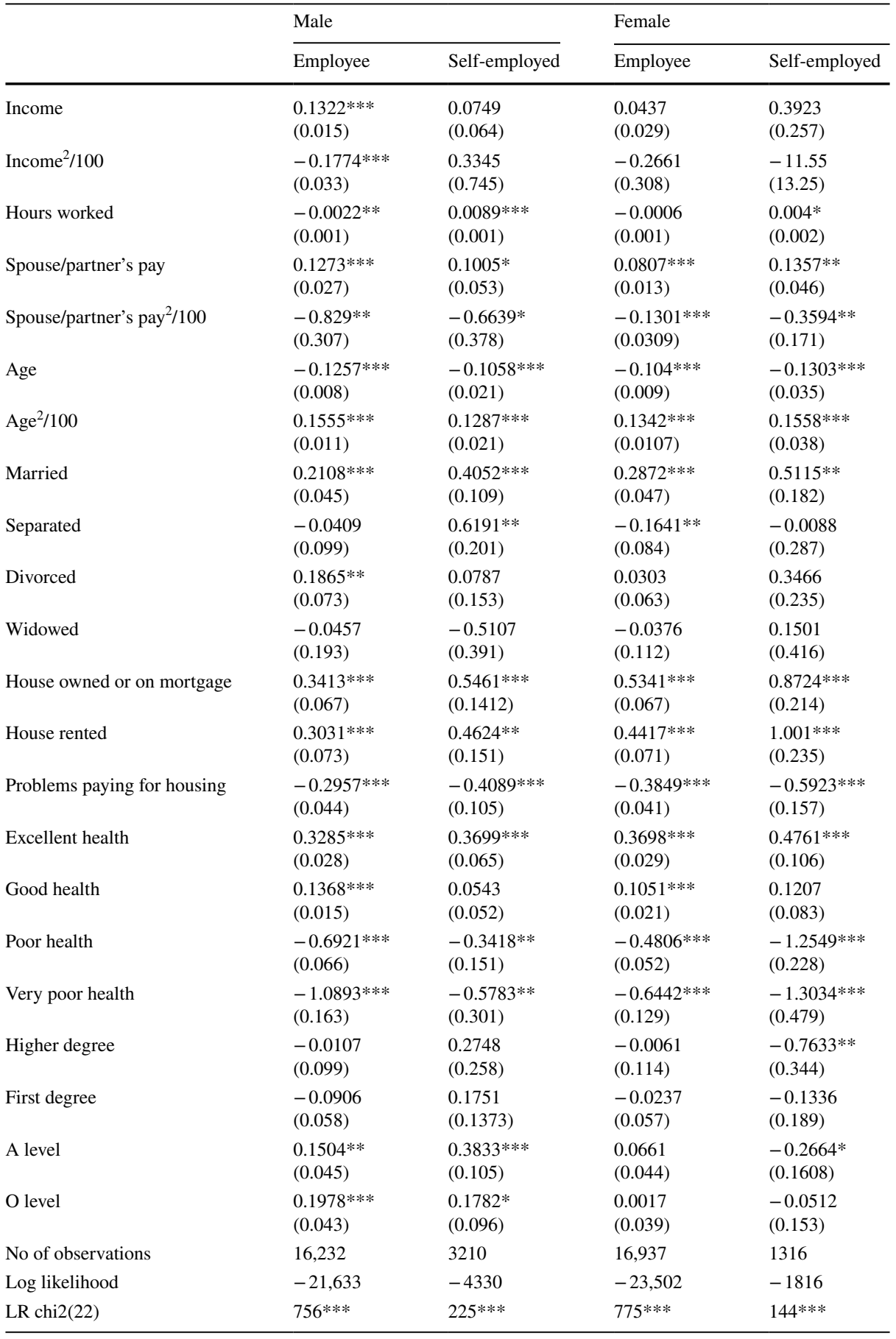

Data from British Household Panel Survey, 1996-2000

$*, * *, * * *$ Denote significance at the 10,5 , and $1 \%$ level, respectively. Standard errors are in parentheses 
Table 2 Determinants of well-being using Ordered Probit Model (2002-2008)

\begin{tabular}{|c|c|c|c|c|}
\hline & \multicolumn{2}{|l|}{ Male } & \multicolumn{2}{|l|}{ Female } \\
\hline & Employee & Self-employed & Employee & Self-employed \\
\hline Log (Income) & $\begin{array}{l}0.1184 * * * \\
(0.011)\end{array}$ & $\begin{array}{l}0.1237 * * \\
(0.054)\end{array}$ & $\begin{array}{l}0.0467 * * * \\
(0.014)\end{array}$ & $\begin{array}{l}0.1417 \\
(0.101)\end{array}$ \\
\hline $\log ^{2}$ (Income) & $\begin{array}{l}-0.1655^{* * * *} \\
(0.031)\end{array}$ & $\begin{array}{l}-0.5672 \\
(0.961)\end{array}$ & $\begin{array}{l}-0.1067 * * * \\
(0.025)\end{array}$ & $\begin{array}{l}-1.3021 \\
(2.022)\end{array}$ \\
\hline Hours worked & $\begin{array}{l}-0.0029 * * * \\
(0.001)\end{array}$ & $\begin{array}{l}0.0079 * * * \\
(0.001)\end{array}$ & $\begin{array}{l}-0.0043^{* * * *} \\
(0.001)\end{array}$ & $\begin{array}{l}-0.0024 \\
(0.0021)\end{array}$ \\
\hline Log(spouse/partner's pay) & $\begin{array}{l}0.0982 * * * \\
(0.019)\end{array}$ & $\begin{array}{l}0.1206^{* *} \\
(0.048)\end{array}$ & $\begin{array}{l}0.0626 * * * \\
(0.009)\end{array}$ & $\begin{array}{l}0.0559^{*} \\
(0.029)\end{array}$ \\
\hline $\log ^{2}$ (spouse/partner's pay) & $\begin{array}{l}-0.6134 * * \\
(0.311)\end{array}$ & $\begin{array}{l}-2.1515^{* *} \\
(1.04)\end{array}$ & $\begin{array}{l}-0.1179 * * * \\
(0.043)\end{array}$ & $\begin{array}{l}-0.0979 \\
(0.081)\end{array}$ \\
\hline Age & $\begin{array}{l}-0.1094 * * * \\
(0.006)\end{array}$ & $\begin{array}{l}-0.0796 * * * \\
(0.015)\end{array}$ & $\begin{array}{l}-0.0595 * * * \\
(0.006)\end{array}$ & $\begin{array}{l}-0.0817 \text { *** } \\
(0.026)\end{array}$ \\
\hline $\mathrm{Age}^{2} / 100$ & $\begin{array}{l}0.1334 \text { *** } \\
(0.007)\end{array}$ & $\begin{array}{l}0.0978 * * * \\
(0.016)\end{array}$ & $\begin{array}{l}0.0707 * * * \\
(0.007)\end{array}$ & $\begin{array}{l}0.0907 \text { *** } \\
(0.028)\end{array}$ \\
\hline Married & $\begin{array}{l}0.2136^{* * * *} \\
(0.036)\end{array}$ & $\begin{array}{l}0.1369 * \\
(0.079)\end{array}$ & $\begin{array}{l}0.2171 * * * \\
(0.036)\end{array}$ & $\begin{array}{l}0.1707 \\
(0.202)\end{array}$ \\
\hline Separated & $\begin{array}{l}-0.1392 * \\
(0.076)\end{array}$ & $\begin{array}{l}-0.0733 \\
(0.162)\end{array}$ & $\begin{array}{l}-0.0334 \\
(0.065)\end{array}$ & $\begin{array}{l}0.2019 \\
(0.274)\end{array}$ \\
\hline Divorced & $\begin{array}{l}0.1443^{* *} \\
(0.059)\end{array}$ & $\begin{array}{l}0.1201 \\
(0.114)\end{array}$ & $\begin{array}{l}-0.0035 \\
(0.049)\end{array}$ & $\begin{array}{l}0.126 \\
(0.175)\end{array}$ \\
\hline Widowed & $\begin{array}{l}-0.1261 \\
(0.146)\end{array}$ & $\begin{array}{l}-0.4264 \\
(0.325)\end{array}$ & $\begin{array}{l}-0.0972 \\
(0.096)\end{array}$ & $\begin{array}{l}-0.0278 \\
(0.347)\end{array}$ \\
\hline House owned or on mortgage & $\begin{array}{l}0.6869 \text { *** } \\
(0.047)\end{array}$ & $\begin{array}{l}0.8688 * * * \\
(0.105)\end{array}$ & $\begin{array}{l}0.7761 \text { *** } \\
(0.044)\end{array}$ & $\begin{array}{l}1.2331^{* * * *} \\
(0.173)\end{array}$ \\
\hline House rented & $\begin{array}{l}0.6258^{* * * *} \\
(0.053)\end{array}$ & $\begin{array}{l}0.8172 * * * \\
(0.122)\end{array}$ & $\begin{array}{l}0.7481 * * * \\
(0.049)\end{array}$ & $\begin{array}{l}1.1895^{* * * *} \\
(0.201)\end{array}$ \\
\hline Problems paying for housing & $\begin{array}{l}-0.3414 * * * \\
(0.041)\end{array}$ & $\begin{array}{l}-0.4116^{* * * *} \\
(0.095)\end{array}$ & $\begin{array}{l}-0.3587 * * * \\
(0.037)\end{array}$ & $\begin{array}{l}-0.6342^{* * * *} \\
(0.151)\end{array}$ \\
\hline Excellent health & $\begin{array}{l}0.6494 * * * \\
(0.029)\end{array}$ & $\begin{array}{l}0.6243 * * * \\
(0.066)\end{array}$ & $\begin{array}{l}0.6317 * * * \\
(0.027)\end{array}$ & $\begin{array}{l}0.9027 * * * \\
(0.105)\end{array}$ \\
\hline Good health & $\begin{array}{l}0.3415^{* * * *} \\
(0.024)\end{array}$ & $\begin{array}{l}0.3852 * * * \\
(0.056)\end{array}$ & $\begin{array}{l}0.3251 * * * \\
(0.023)\end{array}$ & $\begin{array}{l}0.6145 \text { *** } \\
(0.091)\end{array}$ \\
\hline Poor health & $\begin{array}{l}-0.2651 * * * \\
(0.049)\end{array}$ & $\begin{array}{l}-0.277 * * \\
(0.121)\end{array}$ & $\begin{array}{l}-0.3408 * * * \\
(0.041)\end{array}$ & $\begin{array}{l}0.0603 \\
(0.155)\end{array}$ \\
\hline Very poor health & $\begin{array}{l}-0.5055^{* * * *} \\
(0.121)\end{array}$ & $\begin{array}{l}-0.406 \\
(0.297)\end{array}$ & $\begin{array}{l}-0.5456^{* * * *} \\
(0.094)\end{array}$ & $\begin{array}{l}-0.3929 \\
(0.371)\end{array}$ \\
\hline Higher degree & $\begin{array}{l}0.0184 \\
(0.072)\end{array}$ & $\begin{array}{l}0.0788 \\
(0.169)\end{array}$ & $\begin{array}{l}0.0189 \\
(0.075)\end{array}$ & $\begin{array}{l}-0.2506 \\
(0.264)\end{array}$ \\
\hline First degree & $\begin{array}{l}0.0497 \\
(0.045)\end{array}$ & $\begin{array}{l}0.0033 \\
(0.105)\end{array}$ & $\begin{array}{l}0.0598 \\
(0.042)\end{array}$ & $\begin{array}{l}-0.0089 \\
(0.151)\end{array}$ \\
\hline A level & $\begin{array}{l}0.1364 * * * \\
(0.035)\end{array}$ & $\begin{array}{l}0.1354 * \\
(0.0807)\end{array}$ & $\begin{array}{l}0.0861 * * \\
(0.034)\end{array}$ & $\begin{array}{l}0.0785 \\
(0.132)\end{array}$ \\
\hline O level & $\begin{array}{l}0.2672 * * * \\
(0.035)\end{array}$ & $\begin{array}{l}0.1739 * * \\
(0.0791)\end{array}$ & $\begin{array}{l}0.0589 * \\
(0.033)\end{array}$ & $\begin{array}{l}0.1315 \\
(0.129)\end{array}$ \\
\hline No of observations & 23,449 & 4919 & 25,614 & 1887 \\
\hline Log likelihood & $-30,686$ & -6437 & $-34,482$ & -2481 \\
\hline LR $\operatorname{chi} 2(22)$ & $1649 * * *$ & $364 * * *$ & $1561^{* * *} *$ & $184 * * *$ \\
\hline
\end{tabular}

Data from British Household Panel Survey, 2002-2008

$*, * *, * * *$ Denote significance at the 10,5 , and $1 \%$ level, respectively. Standard errors are in parentheses 
Table 3 Determinants of well-being using Ordered Probit Model (2009-2014)

\begin{tabular}{|c|c|c|c|c|}
\hline & \multicolumn{2}{|l|}{ Male } & \multicolumn{2}{|l|}{ Female } \\
\hline & Employee & Self-employed & Employee & Self-employed \\
\hline Income & $\begin{array}{l}0.2851 * * * \\
(0.005)\end{array}$ & $\begin{array}{l}0.0315 \\
(0.021)\end{array}$ & $\begin{array}{l}0.1574 * * * \\
(0.008)\end{array}$ & $\begin{array}{l}-0.0053 \\
(0.031)\end{array}$ \\
\hline Income $^{2} / 100$ & $\begin{array}{l}-1.9944 * * * \\
(0.057)\end{array}$ & $\begin{array}{l}-0.1589 \\
(0.167)\end{array}$ & $\begin{array}{l}-1.1869 * * * \\
(0.101)\end{array}$ & $\begin{array}{l}-0.0227 \\
(0.274)\end{array}$ \\
\hline Hours worked & $\begin{array}{l}-0.0056^{* * * *} \\
(0.001)\end{array}$ & $\begin{array}{l}-0.0010^{*} \\
(0.0005)\end{array}$ & $\begin{array}{l}-0.0081 * * * \\
(0.001)\end{array}$ & $\begin{array}{l}-0.0015^{* * *} \\
(0.0007)\end{array}$ \\
\hline Age & $\begin{array}{l}-0.0681 * * * \\
(0.002)\end{array}$ & $\begin{array}{l}-0.0317 * * * \\
(0.004)\end{array}$ & $\begin{array}{l}-0.0307 * * * \\
(0.002)\end{array}$ & $\begin{array}{l}-0.0352 * * * \\
(0.006)\end{array}$ \\
\hline $\mathrm{Age}^{2} / 100$ & $\begin{array}{l}0.0799 * * * \\
(0.002)\end{array}$ & $\begin{array}{l}0.0403 * * * \\
(0.005)\end{array}$ & $\begin{array}{l}0.0344 * * * \\
(0.002)\end{array}$ & $\begin{array}{l}0.0409 * * * \\
(0.007)\end{array}$ \\
\hline Married & $\begin{array}{l}0.1689 * * * \\
(0.034)\end{array}$ & $\begin{array}{l}0.3895 * * * \\
(0.069)\end{array}$ & $\begin{array}{l}0.3491 * * * \\
(0.046)\end{array}$ & $\begin{array}{l}0.2536 \\
(0.161)\end{array}$ \\
\hline Separated & $\begin{array}{l}-0.1370 \\
(0.127)\end{array}$ & $\begin{array}{l}0.4001 \\
(0.334)\end{array}$ & $\begin{array}{l}0.3562 * * \\
(0.138)\end{array}$ & $\begin{array}{l}-0.9010 \\
(0.798)\end{array}$ \\
\hline Divorced & $\begin{array}{l}0.2530 * * * \\
(0.078)\end{array}$ & $\begin{array}{l}0.5477 * * * \\
(0.154)\end{array}$ & $\begin{array}{l}0.5325 * * * \\
(0.083)\end{array}$ & $\begin{array}{l}0.8195 * * * \\
(0.220)\end{array}$ \\
\hline Widowed & $\begin{array}{l}0.2013 \\
(0.254)\end{array}$ & $\begin{array}{l}1.7528 * * * \\
(0.657)\end{array}$ & $\begin{array}{l}-0.5495^{* *} \\
(0.274)\end{array}$ & $\begin{array}{l}-0.7381 \\
(0.721)\end{array}$ \\
\hline House owned or on mortgage & $\begin{array}{l}0.0957 * * * \\
(0.014)\end{array}$ & $\begin{array}{l}-0.0078 \\
(0.026)\end{array}$ & $\begin{array}{l}0.1277 * * * \\
(0.014)\end{array}$ & $\begin{array}{l}0.1187 * * * \\
(0.037)\end{array}$ \\
\hline House rented & $\begin{array}{l}0.0025 \\
(0.013)\end{array}$ & $\begin{array}{l}-0.1178 * * * \\
(0.031)\end{array}$ & $\begin{array}{l}-0.0608 * * * \\
(0.012)\end{array}$ & $\begin{array}{l}-0.1699 * * * \\
(0.046)\end{array}$ \\
\hline Problems paying for housing & $\begin{array}{l}-0.0511 * * \\
(0.021)\end{array}$ & $\begin{array}{l}-0.1794 * * * \\
(0.043)\end{array}$ & $\begin{array}{l}-0.1415^{* * * *} \\
(0.019)\end{array}$ & $\begin{array}{l}-0.0912 \\
(0.067)\end{array}$ \\
\hline Excellent health & $\begin{array}{l}0.3392 * * * \\
(0.013)\end{array}$ & $\begin{array}{l}0.4156 * * * \\
(0.027)\end{array}$ & $\begin{array}{l}0.4292 * * * \\
(0.012)\end{array}$ & $\begin{array}{l}0.5914 * * * \\
(0.037)\end{array}$ \\
\hline Very good health & $\begin{array}{l}0.2150 * * * \\
(0.011)\end{array}$ & $\begin{array}{l}0.2859 * * * \\
(0.022)\end{array}$ & $\begin{array}{l}0.2123 * * * \\
(0.010)\end{array}$ & $\begin{array}{l}0.3514 * * * \\
(0.032)\end{array}$ \\
\hline Fair health & $\begin{array}{l}-0.2693 * * * \\
(0.016)\end{array}$ & $\begin{array}{l}-0.2093 * * * \\
(0.032)\end{array}$ & $\begin{array}{l}-0.2809 * * * \\
(0.015)\end{array}$ & $\begin{array}{l}-0.2482 * * * \\
(0.050)\end{array}$ \\
\hline Poor health & $\begin{array}{l}-0.5328 * * * \\
(0.036)\end{array}$ & $\begin{array}{l}-0.4163 * * * \\
(0.082)\end{array}$ & $\begin{array}{l}-0.7048 * * * \\
(0.029)\end{array}$ & $\begin{array}{l}-0.3270 * * * \\
(0.100)\end{array}$ \\
\hline Higher degree & $\begin{array}{l}-0.3264 * * * \\
(0.039)\end{array}$ & $\begin{array}{l}-0.5035^{* * * *} \\
(0.088)\end{array}$ & $\begin{array}{l}-0.4110^{* * * *} \\
(0.048)\end{array}$ & $\begin{array}{l}-0.5681 * * * \\
(0.178)\end{array}$ \\
\hline First degree & $\begin{array}{l}-0.2523 * * * \\
(0.252)\end{array}$ & $\begin{array}{l}-0.3136^{* * * *} \\
(0.093)\end{array}$ & $\begin{array}{l}-0.2876^{* * * *} \\
(0.043)\end{array}$ & $\begin{array}{l}-0.1630 \\
(0.145)\end{array}$ \\
\hline A level & $\begin{array}{l}-0.1045^{* * * *} \\
(0.037)\end{array}$ & $\begin{array}{l}-0.5338 * * * \\
(0.100)\end{array}$ & $\begin{array}{l}-0.3289 * * * \\
(0.046)\end{array}$ & $\begin{array}{l}-0.6030 * * \\
(0.304)\end{array}$ \\
\hline O level & $\begin{array}{l}-0.1371 * * * \\
(0.025)\end{array}$ & $\begin{array}{l}-0.5204 * * * \\
(0.055)\end{array}$ & $\begin{array}{l}-0.2639 * * * \\
(0.032)\end{array}$ & $\begin{array}{l}-0.4286 * * \\
(0.167)\end{array}$ \\
\hline No of observations & 55,574 & 13,029 & 64,720 & 6627 \\
\hline Log likelihood & $-84,547$ & $-19,785$ & $-101,427$ & $-10,143$ \\
\hline Wald chi2(20) & $5644 * * *$ & $845 * * *$ & $4620 * * *$ & $544 * * *$ \\
\hline LR test & $89.69 * * *$ & $33.07 * * *$ & $101.7 * * *$ & $4.35 * *$ \\
\hline
\end{tabular}

Data from Understanding Society-UK Household Longitudinal Study: Wave 1-5, 2009-2014

$*, * *, * * *$ Denote significance at the 10,5 , and $1 \%$ level, respectively. Standard errors are in parentheses 


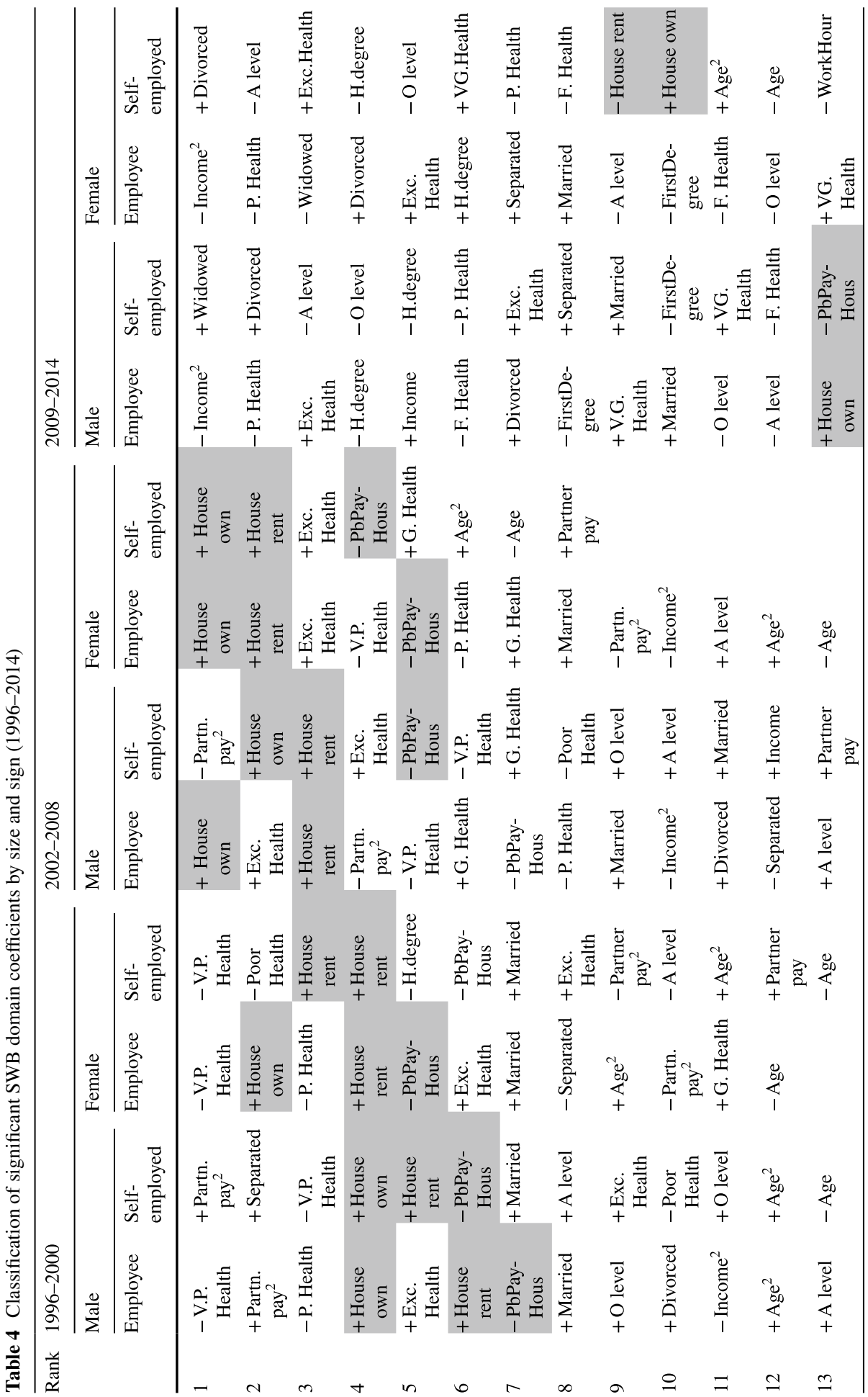




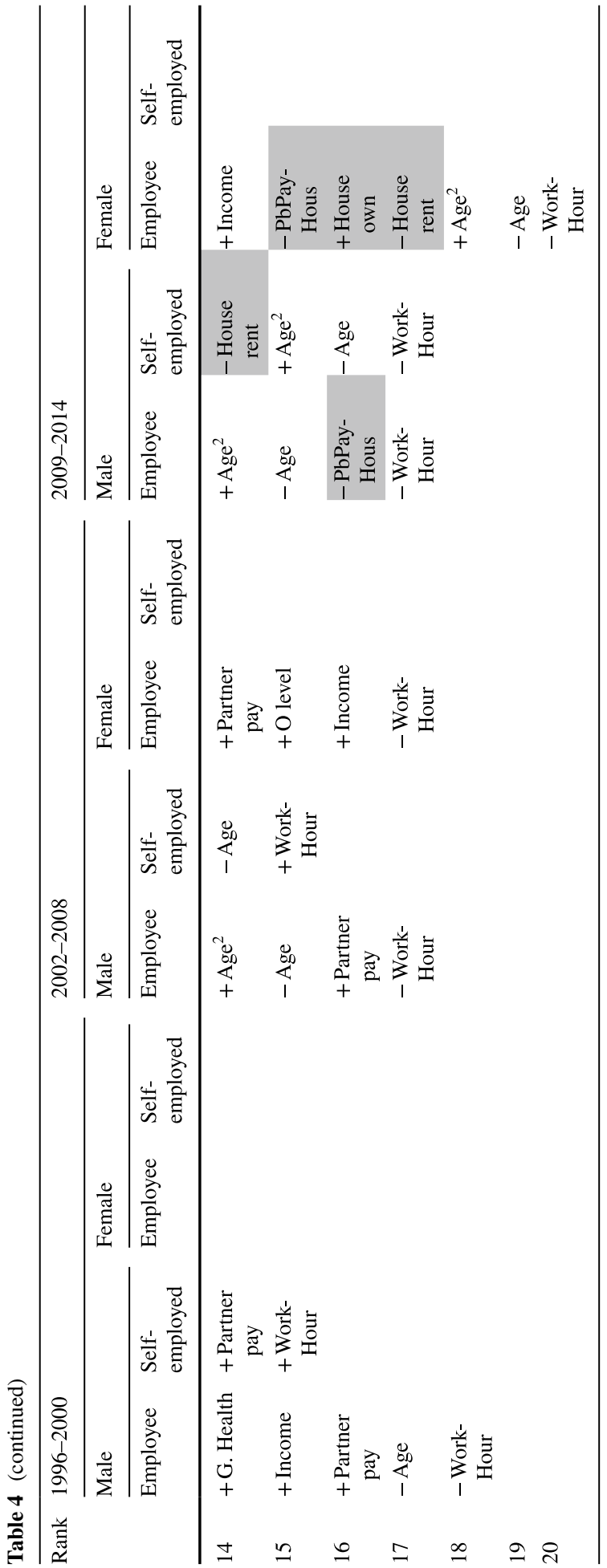


status with the positive coefficients linked to the variables squared partner pay and being separated.

Turning to the SWB domains, Table 4 shows the ranking of the different domains classified by the size, in descending order, of the statistically significant coefficients in each group for the three periods. The domains linked to housing have been shaded to highlight the discrepancies in rating prior to and after the 2008 crisis. In effect, the striking element of Table 4 is that housing factors have improved in ranking from 1996 to 2008 to end at the top of the classification across groups in 2008 before dropping considerably in the post-2008 period. For example, home ownership was classified from 2nd place for female employees to 4th place for other groups in the period 1996-2000, jumping to the 1st rank for male employees, all women, and 2nd rank for self-employed men in the period 2002-2008, and then dropping to the 10th place for self-employed women, 13th place for male employees, 16th place for female employees and not being statistically significant for self-employed men. Similarly, the ranking of the variable "problem paying for housing" followed the same trend of home ownership over the entire 1996-2014 period, when we could expect that such variable would become of great significant in the event of the Great Recession in the post-2008 era. Instead, in the post-2008 era, we observe a different pattern of ranking by professional group. The first satisfaction domain affecting the SWB of employees is the squared income variable, which means that the prospects of income opportunities and associated rising level of uncertainty linked to the Great Recession negatively affect SWB, whether men or women. Poor level of health is the second domains affecting negatively employees' SWB.

In terms of the ranking of life domains by social group, there is some evidence of a group effect being consistent per group. For example, looking at the domain ranked first after 2008, it differs between the self-employed group as a whole-with family status being the major contributor to SWB, and the employee group as whole-with income stability being the major contributor to SWB. Looking at a gender group effect within the self-employed group, being divorced or separated used to be important for self-employed men in affecting positively SWB prior to 2008, and it has become the first domain for selfemployed women too from 2009. Hence, to a certain extent there is a sense that the financial crisis may have reinforced professional group identity. However, the evidence on group effects need further investigation to unpack the overlap of group memberships in SWB measurement. As an area for future research, partitioning SWB samples into subgroups (by social group) could be a way forward to understand the domains valued by these groups and the way the ranking of life domains defines group membership. Similarly, the same ranking methodology on SWB samples of countries not affected by the housing bubble could be compared with the UK group effect.

\section{Conclusion}

Since the Easterlin paradox was unveiled, empirical studies have confirmed its validity, yet the individual mechanisms as to why this phenomenon occurs are not clear. Perception of SWB, via adaption to life circumstances and peer-comparison, has been put forward has an essential element shaping the income threshold in the Easterlin paradox (Mentzakis and Moro 2009) and SWB outcomes in general (Dolan et al. 2008). Our paper provides evidence on the importance of perception in SWB assessment by investigating the bias in individual perception created by group membership from experience utility at time $t-1$ to remembered utility at time $t$. We do so by assessing the ranking of the domains of SWB 
by professional and social group prior to and after the 2008 crisis. The findings suggest a "keeping up with the Joneses" group effect on remembered utility, or life satisfaction, whereby housing domains have steadily increased in importance in influencing SWB up to 2008 before collapsing to the lowest ranks of SWB domains in the post-2008 era. Another group effect appears within each professional group whereby the rankings tend to be similar within the self-employed group or the employee group, with minor gender discrepancies, especially after 2008. Such evidence confirms the presence of peer-comparison in SWB, and raises the issue of the extent to which the Easterlin paradox could be understood in terms of group comparison and the associated relative value of satisfaction domains within and across groups, however defined. As such, for policy-making purpose, especially in a Brexit era, it is important to grasp the extent to which group membership affects individual SWB. In effect, based on the perceived group boundaries of each individual, group membership enables individuals to adapt to any external policy circumstances. Ethical considerations therefore need to account for the positive and negative impact of policy on subjective well-being.

Open Access This article is distributed under the terms of the Creative Commons Attribution 4.0 International License (http://creativecommons.org/licenses/by/4.0/), which permits unrestricted use, distribution, and reproduction in any medium, provided you give appropriate credit to the original author(s) and the source, provide a link to the Creative Commons license, and indicate if changes were made.

\section{References}

Akerlof, G. A., \& Kranton, R. E. (2010). Identity economics: How our identities shape our work, wages, and well-being. Princeton: Princeton University Press.

Arestis, P., Charles, A., \& Fontana, G. (2015). Power, intergroup conflicts and social stratification in the United States: What has the global crisis taught us. Review of Social Economy, 73(4), 370-387.

Bertrand, M., Chugh, D., \& Mullainathan, S. (2005). Implicit discrimination. The American Economic Review, 95, 94-98.

Binder, M., \& Coad, A. (2010). An examination of the dynamics of well-being and life events using vector autoregressions. Journal of Economic Behavior and Organization, 76, 352-371.

Binder, M., \& Coad, A. (2011). From average Joe's happiness to miserable Jane and cheerful John. Journal of Economic Behavior and Organization, 79, 275-290.

Blanchflower, D., \& Oswald, A. (2004). Well-being over time in Britain and USA. Journal of Public Economics, 88, 1359-1386.

Boes, S., \& Winkelmann, R. (2004). Income and happiness: New results from generalized threshold and sequential models. In Working Paper No. 0407, Socioeconomic Institute, Zürich: University of Zurich.

Booth, A. L., \& van Ours, J. C. (2009). Hours of work and gender identity: Does part-time work make the family happier? Economica, 76, 176-196.

Bornstein, G., Kugler, T., \& Ziegelmeyer, A. (2004). Individual and group decisions in the centipede game: Are groups more "rational" players? Journal of Experimental Social Psychology, 40, 599-605.

Brown, A., \& Yang, F. (2015). Does society underestimate women? Evidence from the performance of female jockeys in horse racing. Journal of Economic Behavior and Organization, 111, 106-118.

Burchardt, T. (2005). Are one man's rags another man's riches? Identifying adaptive expectations using panel data. Social Indicators Research, 74(1), 57-102.

Campbell, J. Y., \& Cocco, J. F. (2007). How do house prices affect consumption? Evidence from micro data. Journal of Monetary Economics, 54, 591-621.

Chang, W. (2011). Identity, gender, and subjective well-being. Review of Social Economy, 69(1), 97-121.

Charness, G., \& Sutter, M. (2012). Groups make better self-interested decisions. Journal of Economic Perspectives, 26, 157-176.

Clark, A. E., Etilé, F., Postel-Vinay, F., Senik, C., \& Van der Straeten, K. (2005). Heterogeneity in reported well-being: evidence from twelve European countries. Economic Journal, 115, C118-C132.

Clark, A., Frijters, P., \& Shields, M. (2008). Relative income, happiness, and utility. Journal of Economic Literature, 46, 95-144. 
Crenshaw, K. W. (1989). Demarginalizing the intersection of race and sex: A black feminist critique of antidiscrimination doctrine, feminist theory and antiracist politics. University of Chicago Legal Forum, 129, 139-167.

D’Ambrosio, C., \& Frick, J. R. (2012). Individual wellbeing in a dynamic perspective. Economica, 79, $284-302$.

Diener, E., \& Suh, E. M. (2000). Culture and subjective well-being. Cambridge MA: MIT Press.

Dolan, P., Peasgood, T., \& White, M. (2008). Do we really know what makes us happy? A review of the economic literature on the factors associated with subjective well-being. Journal of Economic Psychology, 29, 94-122.

Easterlin, R. A. (1974). Does economic growth improve the human lot? Some empirical evidence. In R. David \& R. Reder (Eds.), Nations and households in economic growth: Essays in honor of moses abramovitz. New York: Academic Press.

Easterlin, R. A. (1995). Will raising the incomes of all increase the happiness of all? Journal of Economic Behaviour and Organization, 27, 35-48.

Easterlin, R. A. (2005). Building a better theory of well-being. In L. Bruni \& P. L. Porta (Eds.), Economics and Happiness: Framing the analysis. New York: Oxford University Press.

Ferrer-i-Carbonell, A., \& Frijters, P. (2004). How important is methodology for the estimates of the determinants of happiness? Economic Journal, 114, 641-659.

Frey, B. (2008). Happiness: A revolution in economics. Cambridge: MIT Press.

Frijters, P., Haisken-DeNew, J. P., \& Shields, M. A. (2006). Can the large swings in Russian life satisfaction be explained by ups and downs in real incomes. Scandinavian Journal of Economics, 108, 433-458.

Gash, V., Mertens, A., \& Gordo, L. R. (2012). The influence of changing hours of work on women's life satisfaction. The Manchester School, 80(1), 51-74.

Giusta, M. D., Jewell, S. L., \& Kambhampati, U. S. (2011). Gender and life satisfaction in the UK. Feminist Economics, 17, 1-34.

Goette, L., Huffman, D., \& Meier, S. (2006). The impact of group membership on cooperation and norm enforcement: Evidence using random assignment to real social groups. The American Economic Review, 96, 212-216.

Huck, S., Kirchsteiger, G., \& Oechssler, J. (2005). Learning to like what you have. Explaining the endowment effect. The Economic Journal, 115(505), 689-702.

Kahneman, D., \& Krueger, A. B. (2006). Developments in the measurement of subjective well-being. Journal of Economic Perspectives, 20(1), 3-24.

Kahneman, D., \& Tversky, A. (2000). Choices, values and frame. New York: Cambridge University Press.

Knies, G. (Ed.). (2015). Understanding society-UK household longitudinal study: Wave 1-5, 2009-2014, user manual. Colchester: University of Essex.

Layard, R. (2005). Happiness: Lessons from a new science. London: Penguin Allen Lane.

Lelkes, O. (2006). Tasting freedom: Happiness, religion and economic transition. Journal of Economic Behavior and Organization, 59, 173-194.

March, J. G. (1988). Variable risk preferences and adaptive aspirations. Journal of Economic Behavior and Organization, 9(1), 5-24.

McBride, M. (2001). Relative income effects on subjective well-being in the cross-section. Journal of Economic Behavior and Organization, 45, 251-278.

Mentzakis, E., \& Moro, M. (2009). The poor, the rich and the happy: exploring the link between income and subjective well-being. Journal of Socio-Economics, 38, 147-158.

Oswald, A., \& Powdthavee, N. (2008). Does happiness adapt? A longitudinal study of disability with implications for economists and judges. Journal of Public Economics, 92, 1061-1077.

Pouwels, B., Siegers, J., \& Vlasblom, J. D. (2008). Income, working hours, and happiness. Economics Letters, 99, $72-74$.

Rabin, M. (2001). Diminishing marginal utility of wealth cannot explain risk aversion. In D. Kahneman \& A. Tversky (Eds.), Choices, Values and Frames. New York: Cambridge University Press.

Ravallion, M., \& Lokshin, M. (2002). Self-rated economic welfare in Russia. European-Economic Review, 46, 1453-1473.

Rayo, L., \& Becker, G. S. (2005). On the foundations of happiness. Mimeo: University of Chicago.

Stutzer, A., \& Frey, B. S. (2006). Does marriage make people happy, or do happy people get married? Journal of Socio-Economics, 35, 326-347.

The Economist. (2008). Britain's property boom turns to bust: Prepare for a hard landing. Accessed on April 10, 2008 from http://www.economist.com/node/11024646, http://www.economist.com/node/11024646.

Urry, H., Nitschke, J., Dolski, I., Jackson, D., Dalton, K., Mueler, C., et al. (2004). Making a life worth living. Psychological Science, 15(6), 367-372.

Van Praag, B. M. S., Frijters, P., \& Ferrer-i-Carbonell, A. (2003). The anatomy of subjective well-being. Journal of Economic Behavior and Organization, 51, 29-49. 